\title{
Human Resources Behaviour in Goverment Organization (Population and Civil Registration Agency of DKI Jakarta Province)
}

\author{
Dewi Sulistyani \\ Postgraduate Lecturer in Satyagama University, Indonesia \\ dewi.sulistyani@gmail.com
}

\section{Doi:10.5901/mjss.2015.v6n5s5p52}

\section{Abstract}

Population and Civil Registration Agency of DKI Jakarta Province service had not yet shown society-based service. This research aimed to analize Human Resource (HR) behaviour on Population and Civil Registration Agency of DKI Jakarta Province in giving public service in population and civil registration sector. This research used qualitative approach. Data and information were collected from various sources using literature study, document, interviewed and observation method in research location. Research finding showed that those Agency need to maximize HR capacity development, to immediately formulate organizational goal in certain work chain with clear duty, obligation and authority in detail for each individual that is equipped with description on what to perform, what working unit should perform and for what reason those duties are performed. In addition, the government apparatus must be given the improvement of education and training to enhance professionalism. From research result new concept were obtained, that are Leadership Aspect effect HR Capacity Development Aspect. Authority Aspect and professionalism Aspect as those three aspects so much depend on policy issued by leader and implemented leadership type. It also affects the career development apparatus.

Keywords: Capacity Development, Authority and professionalism

\section{Introduction}

Society assumption that service by government institution hasn't shown society-based service has made government institution in various sectors perform service monitoring and evaluation toward society given in their respective institution including population and civil registration agency. Various regions have made improvement effort in its civil registration service system. Though there were still complains delivered by society so that creating gap between vision and facts. Those complains were inter alia on condition and completeness services infrastructure, less service information, and disappointing apparatus behaviour such as less ability to show care toward society, inconsistency between completion time and established standard, service flow application inconsistency. Lack of ability could also be seen from rigidity in giving explanation and panic when receiving complain from society, so that less able to give the alternative solutions. Those complains occur in each level of government in DKI Jakarta Province, from Urban Village, Sub-district, City into Province agency level, so could be interpreted as reflection from Population and Civil Registration Agency of DKI Jakarta Province (Simanjuntak, 2012:4).

Policy, facility and infrastructure of this institutional had been established by leader. HR process and run the organization with foundation of goal, policy, and facility and infrastructure of organization already provided by leader in order to achieve those organization goal. In this matter the placed HR must possess professionalism, understanding limitation of owned power (authority) and having capacity to process and run the organization. The importance of HR also supported by Sedarmayanti (2000:28) that defined HR as: "worker and employee in achieving success."

Though change into improvement in service has occur, but still did not meet society desire, then DKI Jakarta society did not have choices, as there is only one providing civil registration, i.e, Population and Civil Registration Agency of DKI Jakarta Province. On that base, the institution must improve service. Thus, HR Capacity Development, Authority and Professionalism are the three (3) aspects are examined in government implementation especially Population and Civil Registration Agency of DKI Jakarta Province.

\section{Literature Review}

Authority owned by each apparatus must be known of its clarity by knowing what and how things should be done and why we perform such thing will fasten working process and simplify HR management concept of organizational support. As 
stated by Hughes (1994:75), excellent details of duty will simplify member of certain organization knowing what to do, for what and how do we do it. Yorder "Job Clarity" Concept (1988:35) that well details of duty will present clarity of certain duty.

From Grindle and Hilderbrand (1997:18) perspective, there are generally five aspects that could be used to assess capacity of certain service institution; policy, environment, organization, HR and system. This research focused on HR from HR Capacity Development Aspect, Authority Aspect, and Professionalism Aspect inside organization, as this research based on community experience in receiving service in population and civil registration agency.

According Handi Irawan D. (2002: 10), customer satisfaction is determined by the professional staff, who deal directly with customers. Creating the environment ministry in government organizations can empower employees through the optimization of professionalism.

Sinambela (2006: 106) stated that "the role of leadership in the government bureaucracy will determine success in improving the quality of care in the community. Because through the leadership role, government bureaucracy can make decisions quickly and appropriately with regard to problems faced by the service ".

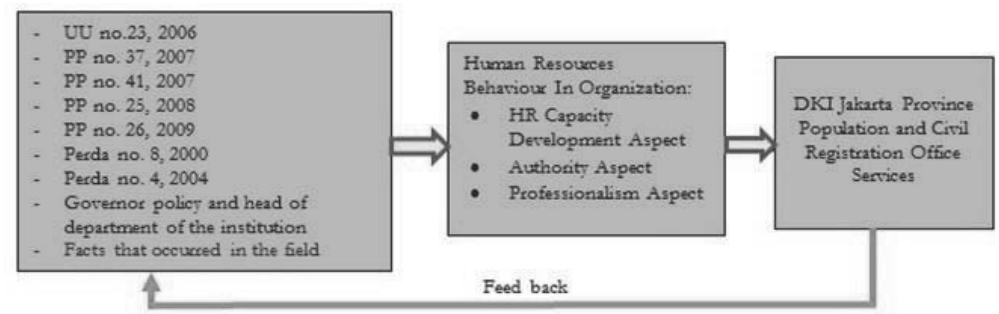

Figure 1. Framework of the research study

\section{Research Method}

Qualitative approach used to describe the state as it is, to experience and discover verstehen, uniqueness deeply, examining the symptoms, observed empirical causality, forming theories and data by Ndraha (2003:29). This research used qualitative approach with research object focus was Population and Civil Registration Agency of DKI Jakarta Province. There were 3 (three) aspects reviewed in this research: HR Capacity Development Aspect, Authority Aspect and Professionalism Aspect.

In this research, for collecting data was also conducted direct observation, interview with individual respondent, or information to examine those data correctness. Respondent in this research were society attenuating civil registration certificate and service apparatus in the intitution. Research location carried out in Population and Civil Registration Agency of DKI Jakarta Province with research schedule from May 2010 into June 2012.

\section{Result and Discussions}

Organization structure regulation are so much depend on knowledge and understanding level of its leader and member on organization structure regulation based on environment dynamic. This also supported by Kartajaya statement (2004:43), in which structure change of certain public service organization commonly carried out to anticipate customer society dynamic, such as economic status, age, life style, environment dynamic and geographical factor. DKI Jakarta Province had performed twice (2) restructuration of its organization. The first one carried out in 2001 which subsequently established with Regional Regulation (Perda). Second change carried out in period of year 2008 until 2009 as adjustment step toward several changes of regulation and laws.

\subsection{Authority Aspect}

In order to achieve organization purpose, all work must be able to be completed in timely manner and accurately, so that organization purpose commonly compiled in certain work chain with clear description of duty, obligation and authority for each individual. Duties and Functions of each position commonly further described into duties of available working unit 
according to echeloneering level position below. Duties description regulation change that could reflect understanding development of leader and member of the institution, from 1999 through 2009

Work description for entire working unit, either new or old structure, do not described in detail, but described as of what to do, what working unit should performed such task and for what reason such task performed, then it could be concluded that duties description formulation in each working unit are unclear in terms of the purpose of those duties. Due to this unclarity, disorientation emerges for apparatus to implement those duties, so that organization purpose could not be achieved and resulting disappointment in society. Therefore in each working unit must be clearly described what to do, what working unit should performed such task and for what reason such task performed, and each of its executive apparatus must clearly understand it, so that organization culture could be achieved and community are served as their expectation. In this terms usually all entire highly dedicated apparatus only have guidance that their duties are solely serving communities as well as they possibly could to satisfy communities.

Of those finding, then it could be seen that in order not causing toward institution capacity decrease, decrease in apparatus loyalty toward institution, from having high work load but treated equally with those who do not work, so that they lost motivation to increase their work achievement and quality. In facing this problem the institution should immediately compile organization purpose in certain work chain with clear description of duties, obligations and authorities on each individual equipped with description on what to do, what working unit should performed such task and for what reason such task performed.

\subsection{HR Capacity Development Aspect}

According to Hughes (1994:76), HR capacity of certain institution could individually discovered from its respective ability in implementing task description. In order to discover institution capacity in HR management, need to be conducted analysis on recruitment pattern, career and skill development pattern, incentive (reward) and sanction (punishment) mechanism. For service implementation capacity need to conduct analysis on work procedure, coordination mechanism, work flow and available service operational standard in implementing services.

The Institution do not have private recruitment pattern, as entire employees obtained from employee distribution carried out by DKI Jakarta Province Regional Secretariat Employment Agency. This Agency only has authority to propose suggestion according to internal need analysis already carried out. According to Hilderbrand and Grindle (1997:87), that is example of recruitment pattern with merit, equity and probity based, recruitment carried out objectively, the presence of opportunity sameness, carried out according to organization need, transparent, and free from personal interest. With those recruitment pattern, could be obtained HR that meet qualification, having quality, dedicated and professional in implementing their task.

From interview result could be obtained that (1) HR with education and task matchness are not always having adequate competency; (2) with this recruitment pattern will generate incompetent HR in its working sectors; (3) is indispensable orientation towards work (4) a possibility that HR need in this agency are unavailable in employment Agency; (5) routine factor becomes apparatus capability support in implementing its task and not finding problems in its implementation. By discovering this information, DKI Jakarta province needs to create education, training and development for its entire apparatus. The most frequent, quality and sustainable in giving education, training and development to executive apparatus then the more quality the service will be given by the Institution to society.

Apparatus capacity development commonly carried out through sustainable training, either for fresh apparatus or apparatus already working for long time, as its purpose are increasing their knowledge and ability in implementing task. This also supported by Chruden and Sherman (1984:181) who stated that even the existing employees need to be trained to refresh them and enable them to keep up with the new methods and techniques of work. Thus, there are 2 (two) training methods: Refresher Training and Introduction Training. Apparatus capacity development method explained by Chruden and Sherman (1984:183), stated that common capacity development carried out in form of training consisting of several methods: On Job Training, Coaching, Job Rotation, Of The Job Training, Lectures/conferences, and Films. Beside that Simulation method also known as training carried out by placing apparatus directly to environment that match with working characteristic will be implemented such as: Cases, Experimental Exercise, Vestibule Training, Role play, Management Games, and In Basket Exercise.

From information obtained and unfounded data on training executed by this Agency since 2001 as have been executed by Domestic Affair Department since 2001. That might be caused by no duties description that regulates training implementation by this Agency Secretariat, as Agency Secretariat duties description are "executing administrative service to entire organization unit in Department environment, employment development, program and budgeting making. Those main duties also not described into duties description, so that duties of employment development are unable to 
discover related to its details. Leader orientation of Regional Development Agency (SKPD) and Local House of Representative (DPRD) in effort of enhancing understanding on meaning and urgency of civil registration service were lastly carried out in 2001, due to unclear duties description.

According to the informant, employee development authority functionally lied in Provincial Regional Secretary of Employment Agency, so that for its employee capacity development, this Agency must coordinate with Employment Agency and Provincial Training Agency that functionally and budgeting having responsibility toward apparatus capacity development duties. Therefore, Hope (1987:137) stated "that personnel training are important part in public institution, then training instructor must be made available." According to obtained information, so far there have never been "Training for Trainer (TOT)" executed in The Institution.

From above description, it could be concluded that there is no special development pattern executed to increase apparatus capacity. This could be proven with the following incident at the time of certificate processing executive apparatus had direct guidance from direct super-ordinate, so it could be said that skill enhancement still carried out informally though that could be said as on job training, but that could not assure on its effectiveness in apparatus capacity development pattern.

With no systematic apparatus capacity development pattern it could cause undeveloped conceptual, technical, technological skills of its entire apparatus. This could cause less competitive ability and maintaining excellent service quality sustainability that become society demand, so that society will become disappointed. Those disappoint will likely make reaction by making complain so that apparatus will receive reprimand from super-ordinate. Reprimand and complain toward apparatus and in other hand apparatus do not have competency, and also not receiving capacity development that could help them implementing their task will result in less caring or frustration that will lead in work quality decrease and the lower loyalty level of apparatus toward organization, as they feel less taken care by their organization. This also supported by Hughes (1994:35), human are not different with machine in which they well maintained, cared and managed will show effective and efficient performance. Conversely, if those steps are not carried out, that will impact on institution performance.

\subsection{Professionalism Aspect}

Education factor are something disappointed in this institution, so that apparatus need to be given education and training enhancement to increase their professionalism that is in accordance with HR capacity development aspect. According Atep Adya Barata (2003: 212) that true professionalism is: (1) Responsible for the job; (2) Always take the initiative to find a way to finish the work well and " solving problem "; (3) Showed a commitment in terms of giving high work standards quality; (4) Always strive to learn and increase knowledge mainly about business and work at their companies are; (5) Learning to think and act in the way people who delegate authority, so as to represent the people when needed; (6) Have the ability to listen and understand and translate into the work - an initiative, not just wait for what was ordered; (7) Team player; (8) Trustworthy, honest and loyal to the company; and (9) Be open to constructive criticism and strive to improve employability.

Indication from poor education level of The Institution could be described at observation period, apparatus could not work fast maximally as they must wait for decision or approval from super-ordinate that could slower working process. This could happen as apparatus do not have authority in making necessary decision needed in serving and responding various societies complain, not responsive toward public aspiration and weak adaptation on changes occur in its environment, so that society value the given service are something less professional. In other words, authority aspect could not be separated from apparatus professionalism aspect. This is in accordance with Agus Prianto (2006:42), explanation that stated that dimension from apparatus professionalism aspect are characterized by innovative, creative, autonomy in working, work consistency, work commitment and career commitment.

Innovative and creative attitude of apparatus so much determined by HR capacity development pattern, something no longer carried out since 2001, and in other hand having direct skill guided by super-ordinate when implementing duties, so that having dependency toward super-ordinate, so that causing time standard retreatment from what has been established and there's assumption of unprofessionalism toward apparatus by the society. This is based on observation result, apparatus work by following various technical procedure of work implementation guidance that are provided, so that its service became rigid and less flexible. This could also become barrier of innovative and creative attitude of the concerned apparatus in effort of understanding their work and facing problems in society services.

Therefore, need to be applied recruitment pattern, career and skill development pattern, incentive and sanction mechanism that is in accordance with available law for apparatus. Beside that, in order to support the creation of high apparatus professionalism, then the Institution immediately compile organization purpose in certain work chain with clear 
description of each individual duties, obligations and authorities which equipped with details on what to do, what working unit must perform and for what reason those task performed. To the management of an enterprise of innovative orientation it is recommended in the stage of recruitment and employment to reveal employees corresponding to the types "active reformer" and "passive reformer". (Kabasheva I.A., Rudaleva I.A., Bulnina I.S., Askhatova L.I.. (2015).

Though at observation society valued, that almost entire apparatus having high commitment toward their career. This is so obviously observed when there is leadership change as all of them try to work even better than they used to be and sometimes performing task that they are not supposed to do, just to receive good appraisal from their new superordinate by increasing their performance so that need of career development could be achieved.

\section{Research Result Implication}

Based on theories and observation result, review on HR behaviour in government organization, especially in Population and Civil Registration Agency of DKI Jakarta Province must be carried out integrally, considering HR Capacity Development Aspect, Authority aspect and Professionalism Aspect in achieving organization goal. The concerned matter described in certain conceptual model as follows (Figure 2):

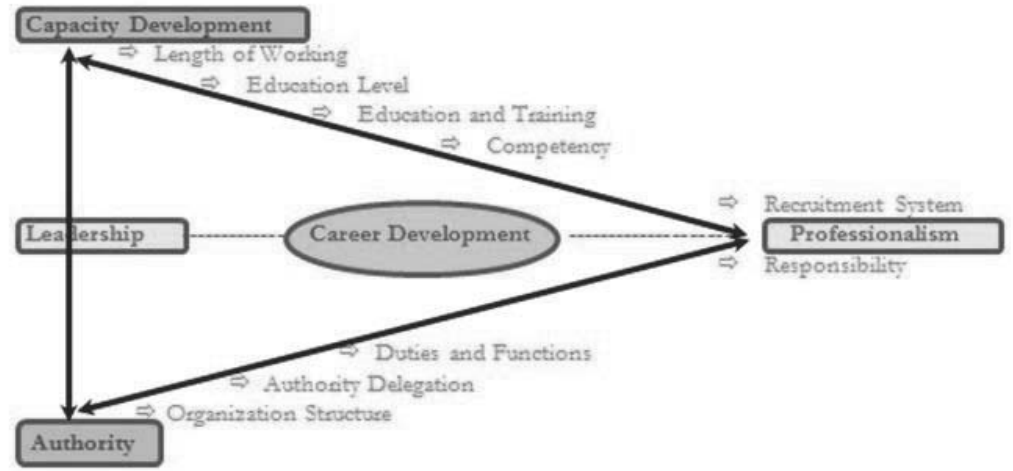

Figure 2. Relatedness Conceptual Model of Autority Aspect, HR Capacity Development Aspect and Professionalism Aspect as Career Development System

From Figure 2, it could be seen that each aspect are inter-connected and affecting each other, for instance in HR Capacity Development, length of work, education level and competency owned by apparatus must be noticed, so that the given training and education according to the need. Those could increase knowledge and understanding on work owned. Increased education level could increase knowledge in science discipline according to their working area, either theoretically or practically to develop creativity and innovation in giving services and complained of society that are served. In this matter correct and proper training education could increase the needed competency, so that apparatus could work simply and correctly according to organization goal. Those two aspects impact could increase Apparatus Professionalism.

Authority Aspect so much influenced by the used Organization structure, especially regulation that need understanding and knowledge on organization structure to achieve organization goal. Thus, duties and functions clarity of each units are needed and also authority delegation of decision maker, so that those apparatus could have responsibility on work and high social impact. In this matter, professionalism aspect of apparatus is so much needed in supporting organization structure regulation and community service acceleration, beside HR capacity development.

Professionalism aspect is the most important in realizing organization goal. Apparatus professionalism are much influenced by recruitment system used and having work responsibility on social impact they could create. In this matter, career development could motivate apparatus to increase their capacity and profesionality, so in the future could obtain bigger authority and having effective leadership capability. With the support of the policy aspects of Capacity Development, Aspect Authority and Professionalism can be increased which means also can develop apparatus career (career development). 
From review of three aspects taking role in supporting HR behaviour in government organization especially Population and Civil Registration Agency of DKI Jakarta Province, it is Leadership Aspect that influenced those three examined aspects. In this matter, in fact, HR Capacity Development Aspect, Authority Aspect and Professionalism Aspect are so much depend on policy issued by leader and implemented leadership pattern.

This finding is supported by Abdullah (2005: 238) stated that "The role of leadership in the context of encouraging the growth of the energy and determination of subordinates, setting organizational goals, challenge and encourage the advancement of subordinates, teach attitude to risk-taking, giving inspiration to employees (executive officers) and assist employees in carrying out their duties, empirically has provided reinforcement to improving the quality of public services.

\section{Conclusion}

Apparatus capacity development commonly carried through sustainable training either for novice apparatus, or apparatus already worked for long time. But its implementation is not recorded since 2001 through 2008 and not so maximum. Thus, need to be applied recruitment pattern, career and potential development pattern, incentive mechanism and sanction according to the needs of institutions and laws that apply for apparatus.

Authority Aspect that could influence HR behaviour in working and serving society are organization structure understanding, authority delegation and clarity of Duties and Function and the embedded responsibility sense toward work. Population and Civil Registration Agency of DKI Jakarta Province must be immediately compile organization goal in certain working chain with clear details of duty, obligation and authority for each individual, equipped with description on what to do, what work unit sector must perform certain task and for what reasons certain task need to perform.

Apparatus HR in order to be able to work professionally they must be given basic knowledge of vision, mission, purpose, structure and work description. HR professionalism level influenced by other aspects such as: leadership, recruitment and placement pattern, training management and apparatus utilization with lack education level, so that apparatus must be given education and training enhancement to increase its professionalism that is in accordance with HR capacity development aspect. Though, society responded and valued that almost entire apparatus have high commitment toward their career.

\section{References}

Abdullah. 2015. Pengaruh Peran Kepemimpinan, Motivasi Kerja, Koordinasi, dan Komitmen Organisasi Terhadap Kualitas Pelayanan Publik Bidang Perizinan Usaha Pada Pemerintah Kabupaten Karimun Provinsi Kepulauan Riau. Jakarta. Universitas Satyagama. Agus Prianto. 2006. Menakar Kualitas Pelayanan Publik. Malang: In-Trans.

Barata, A.A. 2003. Dasar-dasar Pelayanan Prima. Jakarta. PT. Alex Media Komputindo

Chruden, H.J., Sherman, A.W. 1974. Personnel Managment. U.S. South-Western Publishing Co,

Dwiyanto, A. 2006. Mewujudkan Good Governance Melalui Pelayanan Publik. Yogyakarta: Gajah Mada University Press.

Goleman, D. 1995. Emotional Intelligence : what it is and why it matters. New Jersey: Rutgers University Press.

Grindle, M.S. 1997. The Good Goverment Imperative: human resources, organizations and institution in M.S. Grindle (ed.), "Getting Good Government: capacity building in the public sectors of developing countries" halaman 3-28. Harvard University Press.

Hilderbrand, M.E. \& Grindle, M.S. 1997. Building sustainable capacity in the public sector: what can be done. Dalam M.S. Grindle (ed.) "Getting Good Government: capacity building in the public sectors of developing countries" halaman 30-31. Harvard University Press.

Hope, K.R. 1987. Administrative Coruruption and Administrative Reform in Developing Countries, Corruption and Reform 2 (2):127-47.

Hughes, O.E. 1994. Public Management and Administration and introduction. New York: St. Martin's Press.

Irawan H. 2002. 10 Prinsip Kepuasan Pelanggan. Jakarta . PT. Elex Media Komputindo

Kabasheva,I.A., Rudaleva,I.A., Bulnina,I.S., Askhatova L.I. (2015). Organizational Faktor Affecting Employee Innovative Behavior. Mediterranean Journal of Social Sciences, vol 6, No 1 S3, 435-439.

Kartajaya, H. 2004. On Brand, On Differenciation, On Positioning: Seri 9 Element Marketing. Jakarta: Mizan.

Ndraha, T. 2003. Metodologi Ilmu Pemerintahan. Jakarta. Rineka Cipta

Rachmawati, Ike. 2012. Pengaruh Pengembangan Sumber Daya Aparatur terhadap Efektivitas Pelayanan Administrasi Kependudukan di Kabupaten Cianjur. Bandung: Universitas Padjadjaran.

Sedarmayanti. 2000. Reformasi Administrasi Publik, Reformasi Birokrasi dan Kepemimpinan Masa Depan (Mewujudkan Pelayanan Prima dan Kepemerintahan yang Baik). Bandung: Refika Aditama.

Simanjuntak, T.H., 2012. Kapasitas Institusi Pemerintah DKI Jakarta Dalam Pelayanan Catatan Sipil. Bandung: Universitas Padjadjaran. Sinambela, Polak Lijan. 2006. Reformasi Pelayanan Publik. Jakarta. PT. Bumi Aksara 